\title{
Soybean Seed Phenolics, Sugars, and Minerals Are Altered by Charcoal Rot Infection in MG III Soybean Cultivars*
}

\author{
Nacer Bellaloui', Alemu Mengistu², Luiz Henrique Saes Zobiole³, Hamed K. Abbas, \\ My Abdelmajid Kassem 5 \\ ${ }^{1}$ Crop Genetics Research Unit, USDA-ARS, Stoneville, USA \\ ${ }^{2}$ Crop Genetics Research Unit, USDA-ARS, Jackson, USA \\ ${ }^{3}$ Crop Protection R \& D, Dow AgroSciences-Brazil, Cascavel, Brazil \\ ${ }^{4}$ Biological Control of Pests Research Unit, USDA-ARS, Stoneville, USA \\ ${ }^{5}$ Plant Genomics and Biotechnology Lab, Department of Biological Sciences, Fayetteville State University, \\ Fayetteville, USA \\ Email: nacer.bellaloui@ars.usda.gov
}

Received 17 August 2014; revised 4 September 2014; accepted 11 September 2014

Copyright (C) 2014 by authors and Scientific Research Publishing Inc.

This work is licensed under the Creative Commons Attribution International License (CC BY). http://creativecommons.org/licenses/by/4.0/

(c) (i) Open Access

\section{Abstract}

Soybean seed is a major source of phytochemical compounds that impact human health nutrition and livestock meal. Charcoal rot is a disease caused by the fungus Macrophomina phaseolina (Tassi) Goid, and thought to infect the plants through roots by a toxin-mediated mechanism, resulting in yield loss and poor seed quality, especially under drought conditions. Limited information is available on the effect of charcoal rot on seed phytochemical compounds and mineral nutrition in soybean. Therefore, the objective of this research was to investigate the effect of charcoal rot infection on seed phenol, seed coat lignin, isoflavones, and minerals using susceptible (S) (DK 3964) and moderately resistant (MR) (AG 3905) maturity group (MG)III soybean cultivars to charcoal rot. A two-year field experiment was conducted, and infested soil with charcoal rot (infested soil conditions, INF) or control (non-infested soil conditions, NINF) was used. The results showed that the moderately resistant genotype had higher concentrations of seed phenolics, total isoflavones, and seed coat lignin under infested and non-infested conditions and under irrigated or non-irrigated conditions compared with the susceptible genotype. The same general trend was found for seed $K$, $\mathrm{Ca}, \mathrm{P}, \mathrm{Mn}, \mathrm{Zn}, \mathrm{B}$, and $\mathrm{Cu}$ concentrations in the moderately resistant genotype compared with the susceptible genotype. Our research demonstrated that these seed phytochemical constituents may explain the differences between susceptible and moderately resistant cultivars and may play an important role in the resistance to charcoal rot.

*Mention of trade names or commercial products in this publication is solely for the purpose of providing specific information and does not imply recommendation or endorsement by the US Department of Agriculture. 


\section{Keywords}

\section{Charcoal Rot, Isoflavones, Lignin, Minerals, Phenolics}

\section{Introduction}

Soybean is a major crop in the world, and soybean seeds are major oil and soymeal sources in the world for human and animal feed. Soybean seeds contain protein, oil, minerals, sugars, and phenolics. Phenolics are secondary metabolites and have human health benefits because of their antioxidant properties [1]-[4] and contribute to the defense in plants against biotic (fungus, bacteria, virus, and insect infection) or abiotic stresses such as drought and high heat. Phenolics are natural chemical compounds containing a hydroxyl group $(-\mathrm{OH})$ bonded to an aromatic hydrocarbon, and possess an aromatic ring bearing phenol or polyphenol hydroxyl substituents such as esters, methyl ethers, and glycosides [5]. Phenolics are produced via the shikimate-phenyl-propanoids-flavonoids pathways [6] [7], and they can be C6 (simple phenol, benzoquinones), C6-C1 (phenolic acid), C6-C3-C6 (flavonoids, isoflavonoids), (C6)n, or (C6-C3-C6)n (lignins) [8] [9].

Charcoal rot is a major soybean disease, leading to loss in production [10] [11], seed quality [12] [13] (Figure 1), and phytosanitary problems for soybean export [14]. Charcoal rot is caused by the fungus Macrophomina phaseolina (Tassi) Goid which infects plant roots from the soil by a toxin-mediated mechanism. Macrophomina phaseolina secretes two toxins (Figure 2), phaseolinone [15] [16] and (-)-botryodiplodin [17]. Although the mechanisms of charcoal rot infection via toxins are not well understood, infection of crop through the roots is
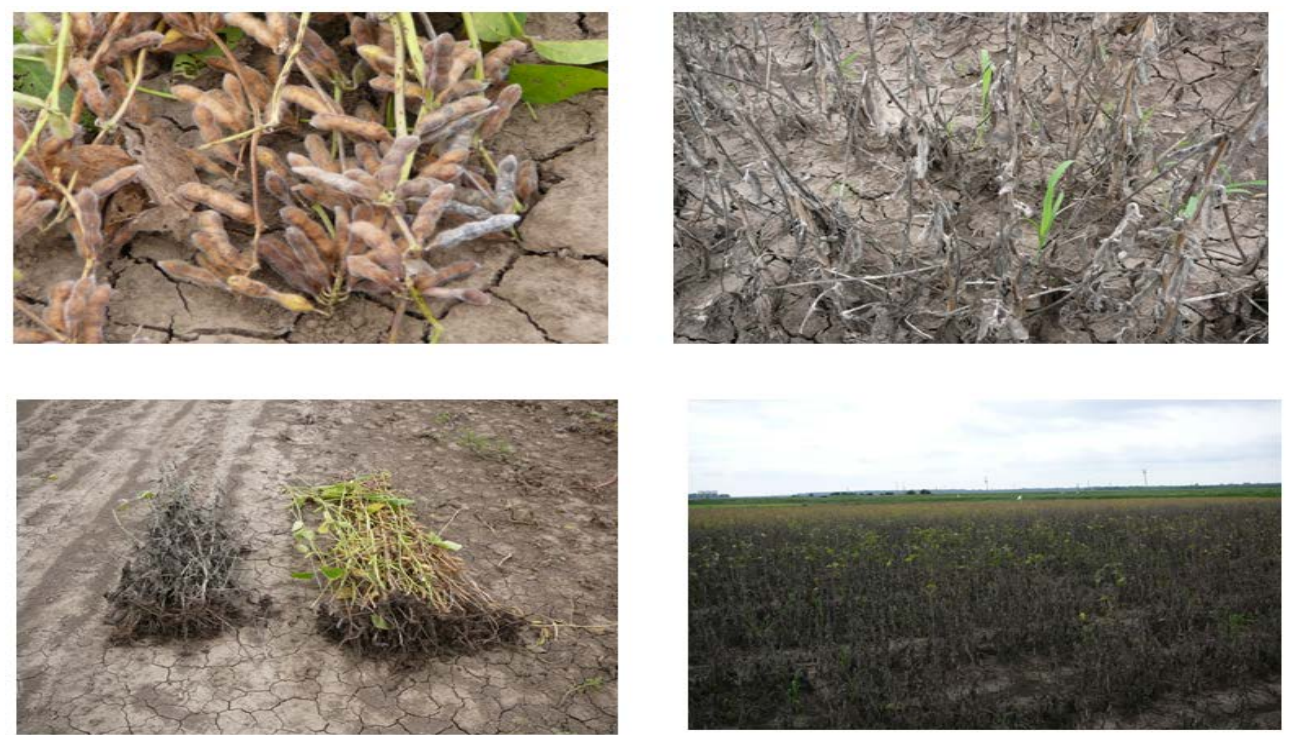

Figure 1. Charcoal rot infestation in the field. Top left = irrigation minimized charcoal rot effects on seed-fill; Top right = soybean grown in non-irrigated field with significant effects of charcoal rot infestation on seed-fill; effect of irrigated (bottom left, soybean on the right) and non-irrigated (bottom left, soybean on the left) on yield loss; Bottom right = Charcoal rot infestation in the field.<smiles>CC(=O)[C@H]1CO[C@@H](O)[C@@H]1C</smiles>

(-)-Botryodiplodin<smiles>C[C@H]1[C@@H](O)CCC2=CC(=O)[C@]3([C@]4(CO)CO4)O[C@@H]3[C@]21C</smiles>

Phaseolinone 
thought to occur by two mechanisms [18]. The first mechanism is through physical penetration of tissue, and the second through secretion of toxins, killing local plant tissue, allowing the fungus to enter through the necrotic area created by the toxin. The toxin-mediated infection of plants occurs 1) by secretion of hydrolytic enzymes or toxins that induce activation of endogenous hydrolytic enzymes; and 2) by secretion of toxins to divide cells, targeting the meristematic tissue at root tips and providing convenient access of the fungus to the vascular system of the infected plant.

Phenolics, including phenol, lignin, and flavonoids are effective inhibitors of hydrolytic enzymes, leading to fungal resistance to toxin-mediated hydrolytic enzymatic infection. Although phenolics were found to be genetically controlled and affected by biotic and abiotic stress factors, the mechanisms of how these factors influence the content and the biosynthesis of phenolics are still not understood. So far there are no commercial soybean cultivars that are fully resistant to charcoal rot disease, and development of soybean genotypes resistant to charcoal rot infection is crucial to manage the disease [19] [20]. For example, a moderately resistant germplasm line DT97-4290 was developed and field-tested and released [21] at Stoneville, MS, USA. The line DT97-4290 was further evaluated for seed protein, oil, and fatty acids [22] and quality [23] in the field under irrigation and nonirrigation and with and without charcoal rot infestation. The moderately resistant (DT97-4290) (maturity group, MG, IV) and AS 3905 (MG III) and susceptible lines (Egyptian and DK 3964) were evaluated under field conditions and with and without irrigation and with and without charcoal rot infestation [11].

Isoflavones are a form of flavonoid in soybean seeds that have multiple chemical functions, including antioxidative actions and health benefits [24]. Isoflavones are categorized based on their functional groups into four subgroups, including aglycons, glucosides, malonylglucosides, and acetylglucosides. Isoflavones occur in storage form as 6-O"-malonyl- $\beta$-glucosides of the respective aglycones genistein, daidzein, and glycitein. The concentration of isoflavoneaglycones is low while significant levels of their simple $\beta$-glucoside (i.e. glucose not conjugated with acetyl or malonyl groups) exist [25]. It was reported that isoflavones prevent certain forms of cancer and reduce risks of cardiovascular diseases [26]. Two forms of isoflavones, genistein and daidzein, have been found to have the ability to control or inhibit the growth of human breast cancer cell lines in culture, and this is may be due to the strong antioxidative properties of genistein [27] [28].

Mechanisms of how phenolics such as lignin and isoflavones contribute to the plant defense against charcoal rot have not been established. It was reported that lignin content in the plants is altered by biotic and abiotic stress factors, indicating complex genetic and physiological control [29]. They reported that abiotic stress factors such as mineral deficiency, drought stress, temperatures, and biotic stress factors such as plant genotype, infection by fungi, bacteria, and viruses can also alter the biosynthesis of lignin in plants [29]. The contribution of lignin to the plant defense may be due to its composition and structure. Lignins are complex racemic aromatic heteropolymersderived fromhydroxycinnamyl alcohol monomers with different methoxylation. These monomers are p-coumaryl, coniferyl, and sinapylalcohols [30]. Lignin occupies the spaces in the cell wall between cellulose, hemicellulose, and pectin, especially in xylemtracheids and vessel elements, creating crosslinkings of polysaccharides, supporting the cell wall [31] [32]. The cell wall polysaccharides are highly hydrophilic, but lignin is more hydrophobic, making vascular tissue of the plants water efficient conductors [32]. Soybean seeds contain phenolic compounds, including chlorogenic acid, caffeic acid, ferulic acid, and $p$-coumaric acid, and the content of these phenolic acids range from $28 \%$ to $72 \%$ of the total phenol. These monolignols produce $p$-hydroxyphenyl, guaiacyl, and syringylphenylpropanoid units when incorporated into the lignin polymer. The content and composition of lignins vary among cell types and individual cell wall layers, and are influenced by environmental stress factors [33]. Lignin constitutes a major component of cell wall, giving rigidity, structural support and impermeability to water [33] and is important for mechanical support, water transport and resistance against pathogens in vascular plants [33] [34]. Previous research showed that lignin deposition is related with mechanical resistance, cell wall protection and microorganism resistance [35], and mechanical damage was related to lignin content and peroxidases activity [36].

Adequate mineral nutrition is crucial to plant defense. It is well established that resistance to pathogens is genetically controlled; however, mineral nutrition can play a major role in resistance or tolerance to pathogens [37] [38]. It was reported that the effect of mineral nutrition is substantial in moderately susceptible, but lower in highly susceptible or resistant to diseases [37]. Previous research showed that minerals such B, Mn, and Cu play a major role in phenolics and lignin synthesis [37] [39] and in cell wall and membrane integrity. Deficiencies of $\mathrm{K}$ and $\mathrm{Zn}$ resulted in high cell wall leakage of sugar and amino acid to leaf apoplast, allowing the pathogen to penetrate the cell [38] [40]; B deficiency led to higher fungal infection [41]; low Ca content in plant tissue re- 
sulted in cell wall leakage of sugars and amino acids from cytoplasm to apoplast; and Cu deficiency led to impairment of defense compound synthesis, accumulation of soluble carbohydrates, and reduced lignin synthesis, resulting in lower disease resistance [38].

Based on the above discussion, it is clear that the plant defense against pathogens is complex, mechanisms explaining the role of phenolics and mineral nutrition are not well understood, and further research in this area is needed. Therefore, the objective of this research chapter was to further investigate the effects of charcoal rot infection on seed phenolics and mineral nutrition in susceptible and moderately resistant cultivars. This research will also review current research in the area of plant resistance and roles of phenolics and mineral nutrition. Since seed sugars were reported to possibly play a significant role under drought conditions, seed sugars (sucrose, raffinose, and stachyose) were also evaluated.

\section{Materials and Methods}

Field trials were conducted in 2004 and 2005 at Delta Research and Extension Center Stoneville, MS $\left(33^{\circ} 26^{\prime} \mathrm{N}\right)$, MS, USA. Irrigated and non-irrigated treatments were imposed. Two soybean maturity group (MG) III cultivars were selected: AG 3905 (moderately resistant) and DK 3964 cultivar (susceptible). Seeds treatment was performed as previously described in [11] [22]. The seeds were treated with mefenoxam (R)-2-\{2,6-(dimethylphenyl)-methoxyacetylamino\}-propionic acid methyl ester fungicide prior to planting as a precaution against stand loss due to Pythium spp. Fumigation with methyl bromide in combination with chloropicrin was conducted two weeks prior to planting as described in details in [11]. The plots were either infested with M. phaseolina or not infested. Planting was 4 May in 2004 and 6 May in 2005. Plants were harvested in mid-September. The treatments were: irrigated-infested and irrigated-noninfested; nonirrigated-infested and nonirrigated-noninfested. The experiment was furrow irrigated, and irrigation was applied whenever water potential reached -50 $\mathrm{kPa}$ at $30 \mathrm{~cm}$ depth. Soil water potential was monitored using tensiometers according to others [22] [42] [43]. Irrigation was applied as described elsewhere [11]. Seeds from each replicate and each treatment were harvested at harvest maturity (R8) for seed composition and phenolics analyses.

\subsection{Disease Assessment and Scoring}

Disease was measured by the intensity of discoloration on a scale of 1 - 5 as described elsewhere [11], in which 1 $=$ no discoloration and $5=$ highly discolored. The scale for root and stem disease severity was based on those of [21], and it was divided into four classes as follows: resistant (values of 1), moderately resistant (values $>1$ and $\leq 2$ ), moderately susceptible (values $>2$ and $<3$ ), and susceptible (values $3-5$ ). In addition to the discoloration scale method, disease assessment was also made in this experiment using colony forming unit (CFU) according to [23]. In the CFU method, assessment of host tissue colonization by M. phaseolina was conducted on three replications by destructively sampling 10 plants at the R7 growth stage. Samples included both roots and aboveground portions of the plant. Samples were taken from the lower stem and root, including lateral and fibrous roots as described elsewhere [23]. The total counts of CFU were taken from each plot, converted to CFU per gram (CFU count $\times 200$ ) of ground root and stem tissue, and expressed for each genotype [23].

\subsection{Lignin Determination in Seed Coat}

Lignin in the seed coat of matured seed was determined as previously reported by others [44]-[46]. Briefly, seeds were soaked for $12 \mathrm{~h}$, then the seed coat was removed, and dried in an oven for $16 \mathrm{~h}$ at $105^{\circ} \mathrm{C}$. A sample of 250 $\mathrm{mg}$ of dry seed coat was homogenized in $50 \mathrm{mM}$ potassium phosphate buffer $(7 \mathrm{~mL}$ at $\mathrm{pH} 7.0)$ with a mortar and pestle. The centrifugation (1400 g for 10 minutes) of the mixture was conducted according to others [47] [48]. The pellet resulting from the centrifugation was washed and centrifuged twice with $7 \mathrm{~mL}$ phosphate buffer at $\mathrm{pH}$ 7.0; $3 \times$ with $7 \mathrm{ml} 1 \%(\mathrm{v} / \mathrm{v})$ Triton X-100 at $\mathrm{pH} 7.0$ buffer; $2 \times$ with $7 \mathrm{ml} 1 \mathrm{M} \mathrm{NaCl}$ at $\mathrm{pH} 7.0$ buffer; $2 \times$ with $7 \mathrm{ml}$ of distilled water; and $2 \times$ with $5 \mathrm{ml}$ acetone. The pellet was then dried in an oven at $60^{\circ} \mathrm{C}$ for $24 \mathrm{~h}$, and placed in a centrifuge tube containing a reaction mixture of $1.2 \mathrm{ml}$ thioglycolic acid with $6 \mathrm{~mL} 2 \mathrm{M} \mathrm{HCl}$. After heating and cooling, the mixture was centrifuged at $1400 \mathrm{~g}$ for $5 \mathrm{~min}$, and the supernatant discarded. The pellet containing the lignin-thioglycolic acid (LTGA) complex was washed $3 \times$ with $7 \mathrm{ml}$ distilled water and then extracted by shaking at $30^{\circ} \mathrm{C}$ for $18 \mathrm{~h}$ at 115 oscillations $\mathrm{min}^{-1}$ in $6 \mathrm{ml}$ of $0.5 \mathrm{M} \mathrm{NaOH}$, centrifuged at $1400 \mathrm{~g}$ for $5 \mathrm{~min}$, and the supernatant was stored at $-20^{\circ} \mathrm{C}$. The chemical washing of the combined pellet and supernatant was con- 
ducted according to [18]. The concentration of lignin was measured by reading the supernatant at absorbance at $280 \mathrm{~nm}$ using a Beckman Coulter DU 800 spectrophotometer (Fullerton, CA). The concentration of lignin was expressed as mg LTGA/g dry weight.

\subsection{Determination of Total Phenol Concentration}

The concentration of total phenol was measured in mature seeds using the Folin-Ciocalteu assay and gallic acid as standard base according to others [49] with modification [50]. Briefly, seeds were ground and passed through a 60-mesh sieve, and a sample of 0.5 was extracted twice with $10 \mathrm{ml}$ acetone/water (50:50, v/v). An aliquot of $200 \mu \mathrm{l}$ of seed extract and $1 \mathrm{ml}$ Folin-Ciocalteu reagent were mixed. Then $1.0 \mathrm{ml}$ of $20 \% \mathrm{Na}_{2} \mathrm{CO}_{3}$ was added with distilled water to make a $5 \mathrm{~mL}$ final volume. The color development occurred after 90 min of incubation at room temperature. The concentration of total phenol was measured spectrophotometrically by reading the samples at $765 \mathrm{~nm}$ using a Beckman Coulter DU 800 spectrophotometer (Fullerton, California). The concentration of total phenol was expressed as mg GAE (gallic acid equivalent) per $100 \mathrm{~g}$ of sample (mg GAE/100g).

\subsection{Analysis of Isoflavones}

The concentration of the total isoflavones (daidzein, genistein, and glycitein) was measured in mature seeds. About $25 \mathrm{~g}$ of seed were ground using a Laboratory Mill 3600 (Perten, Springfield, IL). Isoflavones were measured according to others [18] [51] [52] using a near-infrared reflectance (NIR) diode array feed analyzer (Perten, Spring Field, IL). The analysis was conducted on a dry matter basis. Total isoflavones were considered the sum of the major three individual isoflavones daidzein, genistein, and glycitein.

\subsection{Determination of Seed Sucrose, Raffinose, and Stachyose Concentrations}

Concentration of seed sucrose, raffinose, and stachyose was measured in R8 seed according to others [53] [54] using an AD 7200 diode array feed analyzer (Perten, Springfield, IL). Briefly, about $25 \mathrm{~g}$ of seed were ground using a Laboratory Mill 3600 (Perten, Springfield, IL). Initial calibration equations were developed by the Department of Agronomy and Plant Genetics, University of Minnesota St. Paul, MN using Thermo Galactic Grams PLS IQ software, developed by Pertencompany (Perten, Springfield, IL). Analyses of sugars were performed based on a seed dry matter basis [53].

\subsection{Seed Glucose Determination}

The concentration of glucose in mature seeds was measured according to the enzymatic reaction using Glucose (HK) Assay Kit from Sigma, USA, Product Code GAHK-20 [55]. In this reaction, glucose is phosphorylated by adenosine triphosphate (ATP) in a reaction catalyzed by hexokinase. Glucose-6-phosphate (G6P) resulting is then oxidized to form 6-phosphogluconate in the presence of oxidized nicotinamide adenine dinucleotide (NAD) in a reaction catalyzed by glucose-6-phosphate dehydrogenase (G6PDH). An equimolar amount of NAD is reduced to NADH during this oxidation, and the increase in absorbance at $340 \mathrm{~nm}$ is directly proportional to glucose concentration in the sample. Mature seed samples were ground using a Laboratory Mill 3600 (Perten, Springfield, IL) to obtain uniform particles. A dry, ground sample of $0.1 \mathrm{mg}$ was extracted with deionized water. The extraction procedure of glucose from seeds was conducted as described elsewhere [56], and as instructed by Glucose (HK) Assay Kit from Sigma. To measure the concentration of glucose, the absorbance of the samples was read at $340 \mathrm{~nm}$ using a Beckman Coulter DU 800 spectrophotometer (Fullerton, CA). The concentration of glucose was expressed as $\mathrm{mg} \cdot \mathrm{g} \cdot \mathrm{dwt}^{-1}$.

\subsection{Seed Fructose Determination}

The concentration of fructose in mature seeds was determined enzymatically according to Fructose Assay Kit from Sigma, USA, Product Code FA-20 [57]. In this reaction, fructose is phosphorylated by ATP in a reaction catalyzed by hexokinase, and the resulting fructose 6-phosphate is then converted to G6P by phosphoglucose isomerase (PGI). Then, oxidation of G6P to 6-phosphogluconate takes place in the presence of NAD in the reaction catalyzed by glucose-6-phosphate dehydrogenase (G6PDH). An equimolar amount of NAD is reduced to $\mathrm{NADH}$, and the consequent increase in absorbance at $340 \mathrm{~nm}$ is directly proportional to fructose concentration in a sample. A sample of $0.1 \mathrm{mg}$ was extracted according to Fructose Assay Kit from Sigma, and is detailed else- 
where [56] as instructed by Fructose Assay Kit from Sigma. The concentration of fructose in samples was determined spectrophotometrically by reading the samples at absorbance of $340 \mathrm{~nm}$ using a Beckman Coulter DU 800 spectrophotometer (Fullerton, CA). The concentration of fructose was expressed as $\mathrm{mg} \cdot \mathrm{g} \cdot \mathrm{dwt}^{-1}$.

\subsection{Boron Determination}

Total boron in mature seeds at R8 was measured according to others [49] [58] [59] using the Azomethine-H method. Briefly, one g of dry, ground sample was ashed at $500^{\circ} \mathrm{C}$ for $8 \mathrm{~h}$, the samples were extracted with $20 \mathrm{ml} 2$ $\mathrm{M} \mathrm{HCl}$ at $90^{\circ} \mathrm{C}$ for $10 \mathrm{~min}$, and the extract was filtered. A sample of $2 \mathrm{ml}$ was added to $4 \mathrm{ml}$ buffer solution (containing 25\% ammonium acetate, 1.5\% EDTA, and 12.5\% acetic acid) and $4 \mathrm{ml}$ azomethine- $\mathrm{H}$ solution containing $0.45 \%$ azomethine- $\mathrm{H}$ and $1 \%$ ascorbic acid [60]. Boron concentration was measured by reading the samples at 420 nm using a Beckman Coulter DU 800 spectrophotometer (Fullerton, CA).

\subsection{Iron Measurement}

The concentration of iron in seeds was measured after acid $\left(60 \% \mathrm{~m} / \mathrm{m} \mathrm{HClO}_{4}+70 \% \mathrm{~m} / \mathrm{m} \mathrm{HNO}_{3}\right)$ wet digestion, extraction, and reaction of the reduced ferrous Fe with 1, 10-phenanthroline according to others [61] [62]. The seed samples were acid digested. Detailed extraction procedures and measurements were detailed in [63]. Briefly, $2 \mathrm{~g}$ of dried ground seed was acid digested, then the acids were removed by volatilization, and the soluble constituents were dissolved in $2 \mathrm{M}$ of $\mathrm{HCl}$. To prepare the standard curve, iron standard solutions were prepared in $0.4 \mathrm{M} \mathrm{HCl}$, ranging from 0.0 to $4 \mu \mathrm{g} \cdot \mathrm{ml}^{-1}$ of $\mathrm{Fe}(\mathrm{II})$. A phenanthroline solution of $0.25 \%(\mathrm{w} / \mathrm{v}$ ) was prepared in $25 \%$ (v/v) ethanol. Quinol solution of $1 \% \mathrm{w} / \mathrm{v}$ was used as reagent. A mixture of $4 \mathrm{ml}$ of a sample in $1 \mathrm{ml}$ of 0.4 $\mathrm{M} \mathrm{HCl}$ and $1 \mathrm{ml}$ of quinol solution were added and mixed, then $3 \mathrm{ml}$ of the phenanthroline solution and $5 \mathrm{ml}$ of the tri-sodium citrate solution ( $8 \% \mathrm{w} / \mathrm{v})$ were added. The solution was diluted to $25 \mathrm{ml}$ with distilled water and incubated at room temperature for $4 \mathrm{~h}$. The concentration of Fe in samples was measured spectrophotometrically by reading at $510 \mathrm{~nm}$ using a Beckman Coulter DU 800 spectrophotometer.

\subsection{Phosphorus Measurement}

The concentration of phosphorus in seeds was measured spectrophotometrically as the yellow phosphor-vanadomolybdate complex according to [64] and detailed in previous reports [63]. Briefly, a dried ground seed sample of $2 \mathrm{~g}$ was ashed, $10 \mathrm{ml}$ of $6 \mathrm{M} \mathrm{HCl}$ was added, and then the sample was evaporated to dryness using a water bath. Two milliliters of $36 \% \mathrm{v} / \mathrm{v} \mathrm{HCl}$ was added to the sample under heat until boiled. The extraction, filtration, and measurement using $5 \mathrm{M} \mathrm{HCl}$ and $5 \mathrm{ml}$ of ammonium molybdate-ammonium metavanadate reagent were detailed elsewhere [63]. Phosphorus concentration in samples was determined using a Beckman Coulter DU 800 spectrophotometer at $400 \mathrm{~nm}$. Dihydrogen orthophosphates was used to produce a standard curve of phosphorus standard solutions $\left(0-50 \mu \mathrm{g} \cdot \mathrm{ml}^{-1}\right.$ of $\left.\mathrm{P}\right)$.

\subsection{Seed Mineral Analyses (N, Ca, Mg, S, and Zn)}

Mature seeds at R8 were collected, and seed mineral concentrations were determined. Seed samples were ground to pass through a $1 \mathrm{~mm}$ sieve using a Laboratory Mill 3600 (Perten, Springfield, IL). Seed N, S, Ca, Mg, and Zn concentrations were analyzed using inductively coupled plasma (ICP) spectrometry as described by others [63]. Nitrogen and S were determined using an elemental analyzer (LECO CNS-2000, LECO Corporation, MI) [63].

\subsection{Experimental Design and Statistical Analysis}

The design was a split plot with irrigation as the main plot, infestation as subplot, and genotype as sub-subplot. Proc GLM in SAS was used for data analysis [65]. Three replicates were used. Fisher's Least Significant Difference test with $5 \%$ as the level of significance was used to separate means.

\section{Results}

\subsection{Soil Infestation and Plant Infection}

Charcoal rot infection to $\mathrm{S}$ and MR cultivars, expressed as colony forming unit per gram (CFU/g), showed that the S cultivar DK 3964 was significantly $(\mathrm{P} \leq 0.05)$ infected with charcoal rot compared with the MR cultivar 
AG 3905 under IRR or NIRR conditions (Figure 3 and Figure 4). The level of infection in NIRR and INF was the highest and the level of magnitude of infection between $\mathrm{S}$ and MR cultivars was extremely large. Therefore, infested soil with charcoal rot resulted in significant infection to S cultivar compared with MR cultivar, and the differences between $\mathrm{S}$ and MR cultivars in seed phenolics, sugars, and minerals can be explained in terms of infection as well as infestation.

\subsection{Analysis of Variance}

Analysis of variance showed that year (Y), infestation treatment (T), cultivar (Cv), and irrigation (Ir) had significant effects on total phenol, lignin, isoflavones, and specific minerals in seeds (Table 1). There were significant differences in the interaction among these factors for phenol, lignin, isoflavones, and minerals, indicating that the infestation effects depended on cultivar, irrigation, and year. Because of these interactions, the results were presented by each year and by each irrigation treatment. Analysis of variance showed that year, infestation treatment, cultivar, and irrigation had significant effects on sugars (glucose, fructose, sucrose, raffinose, and stachyose) in seeds (Table 2). There were significant differences in the interaction among these factors for sugars, indicating that the infestation effects depended on cultivar, irrigation, and year. Because of the significant effects of the interactions between the main factors, the results were presented by year and irrigation treatment.

\subsection{Effect of Charcoal Rot Infestation on Seed Phenol, Lignin, Total Isoflavones, and Minerals under Irrigated Conditions}

Seed phenol, lignin, and total isoflavone concentrations were higher in MR cultivar than in S cultivar under infestation (INF) than under non-infestation (NINF) conditions (Table 3). Seed phenol, lignin, and isoflavones in

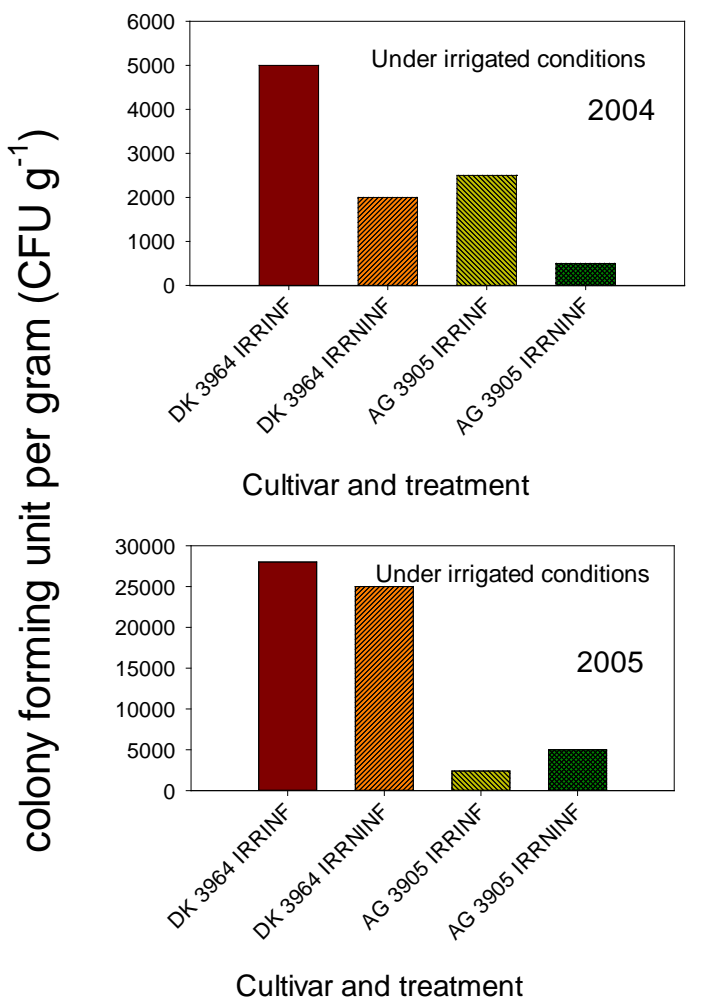

Figure 3. Charcoal rot levels (colonyforming unit per gram (CFU g ${ }^{-1}$ ) in susceptible cultivar (DK 3964) underirrigate-dinfested (DK 3964 IRRINF) and irrigated noninfested (DK 3964 IRRNINF) and in moderatelyresistant cultivar (AG 3905) underirrigatedinfested (AG 3905 IRRINF) and irrigated non-infested (AG 3905 IRRNINF) in 2004 and 2005. 


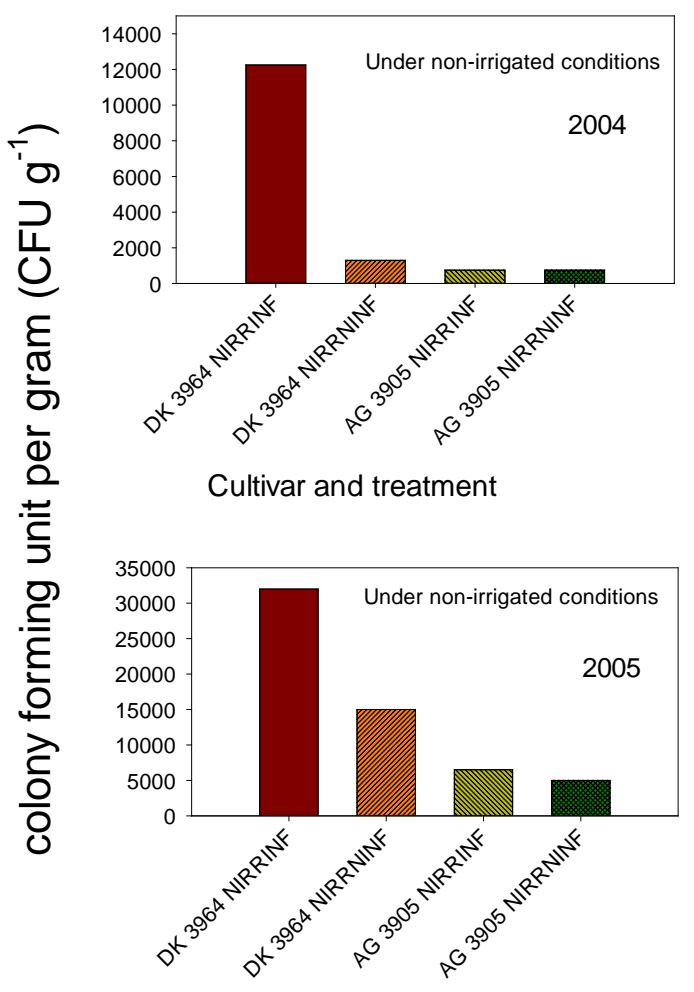

Cultivar and treatment

Figure 4. Charcoal rot levels (colonyforming unit per gram (CFU g ${ }^{-1}$ ) in susceptible cultivar (DK 3964) under non-irrigate-dinfested (DK 3964 NIRRINF) and nonirrigated non-infested (DK 3964 NIRRNINF) and in moderatelyresistant cultivar (AG 3905) under non-irrigatedinfested (AG 3905 NIRRINF) and non-irrigated non-infested (AG 3905 NIRRNINF) in 2004 and 2005.

Table 1. Analysis of variance of the effects of year (Y), charcoal rot infestation treatment (T), cultivar (Cv), and irrigation (Ir) on seed total phenol, seed coat lignin, total isoflavones, nitrogen, and minerals in susceptible (DK 3964) and moderately resistant (AG 3905) soybean cultivars to charcoal rot infestation.

\begin{tabular}{|c|c|c|c|c|c|c|c|c|c|c|c|c|c|}
\hline Source of variability & Phenol & Lignin & Total isoflavones & $\mathrm{N}$ & $\mathrm{P}$ & K & $\mathrm{Ca}$ & $\mathrm{Mg}$ & $\mathrm{Mn}$ & B & $\mathrm{Zn}$ & $\mathrm{Fe}$ & $\mathrm{Cu}$ \\
\hline Year (Y) & $* * *$ & $*$ & $* *$ & $*$ & $*$ & $*$ & $*$ & $* *$ & $*$ & $* *$ & $*$ & $*$ & $*$ \\
\hline Treatment $(\mathrm{T})$ & $*$ & $*$ & $*$ & $*$ & $*$ & $* *$ & $* *$ & $* * *$ & * & * & $*$ & $*$ & $*$ \\
\hline $\begin{array}{l}\text { Cultivar (Cv) } \\
\text { Irrigation (Ir) }\end{array}$ & $*$ & * & $*$ & $* *$ & $*$ & $*$ & $*$ & $*$ & * & $*$ & NS & $*$ & $*$ \\
\hline $\mathrm{Y} \times \mathrm{T}$ & $* *$ & $*$ & $* * *$ & $* *$ & $*$ & $*$ & $*$ & $* *$ & $* *$ & $* *$ & $*$ & $*$ & $*$ \\
\hline $\mathrm{Y} \times \mathrm{Cv}$ & NS & $*$ & $* *$ & NS & $* *$ & $*$ & NS & NS & $* *$ & $*$ & * & $*$ & $*$ \\
\hline $\mathrm{Y} \times \mathrm{Ir}$ & $*$ & $* *$ & $* * *$ & $* *$ & $*$ & $* *$ & $* *$ & $*$ & $*$ & $* * *$ & $* *$ & $*$ & $*$ \\
\hline $\mathrm{T} \times \mathrm{Cv}$ & $*$ & $*$ & $*$ & NS & $*$ & $* *$ & $* *$ & NS & NS & $*$ & $* *$ & $*$ & $*$ \\
\hline $\mathrm{T} \times \mathrm{Ir}$ & $* *$ & $*$ & $* * *$ & NS & $*$ & $* *$ & $* *$ & NS & NS & $* *$ & $*$ & $*$ & $* *$ \\
\hline $\mathrm{Cv} \times \mathrm{Ir}$ & $*$ & $*$ & $* *$ & $*$ & $*$ & $* *$ & $* *$ & $*$ & $*$ & $* *$ & $*$ & $* *$ & $* *$ \\
\hline $\mathrm{Y} \times \mathrm{T} \times \mathrm{Cv}$ & $* *$ & $* *$ & $* * *$ & * & $*$ & $*$ & $*$ & * & * & * & $* *$ & $*$ & * \\
\hline $\mathrm{Y} \times \mathrm{T} \times \mathrm{Ir}$ & $*$ & $*$ & $* * *$ & $* *$ & $* *$ & $*$ & $*$ & $*$ & $*$ & $*$ & $*$ & $*$ & $* *$ \\
\hline $\mathrm{T} \times \mathrm{Cv} \times \mathrm{Ir}$ & $*$ & $* *$ & $* *$ & * & $*$ & $* *$ & $* *$ & $* *$ & $*$ & $* *$ & $*$ & $*$ & $* *$ \\
\hline $\mathrm{Y} \times \mathrm{CV} \times \mathrm{Ir}$ & $*$ & * & $* * *$ & * & * & $*$ & $*$ & * & * & $* *$ & $*$ & $*$ & * \\
\hline $\mathrm{Y} \times \mathrm{T} \times \mathrm{Cv} \times \mathrm{Ir}$ & $*$ & $*$ & $* * *$ & $* *$ & $* *$ & $*$ & $*$ & $*$ & $*$ & $* * *$ & $* *$ & $*$ & $*$ \\
\hline
\end{tabular}

$*$ : Significance at $\mathrm{P} \leq 0.05 ; * *$ : Significance at $\mathrm{P} \leq 0.01 ; * * *$ : Significance at $\mathrm{P} \leq 0.001$. 
Table 2. Analysis of variance of the effects of year (Y), charcoal rot infestation treatment (T), cultivar (Cv), and irrigation (Ir) on seed sugars (mg/g) in susceptible (DK 3964) and moderately resistant (AG 3905) soybean cultivars to charcoal rot infestation.

\begin{tabular}{|c|c|c|c|c|c|}
\hline Source of variability & Glucose & Fructose & Sucrose & Raffinose & Stachyose \\
\hline Year (Y) & $* *$ & $*$ & $* * *$ & * & $* * *$ \\
\hline Treatment (T) & $* *$ & $*$ & $* * *$ & * & $* *$ \\
\hline Cultivar (Cv) & $*$ & $*$ & $*$ & $*$ & $*$ \\
\hline Irrigation (Ir) & $* *$ & $*$ & $*$ & $*$ & $* *$ \\
\hline $\mathrm{Y} \times \mathrm{T}$ & $* *$ & * & $* *$ & $*$ & $*$ \\
\hline $\mathrm{Y} \times \mathrm{Cv}$ & NS & * & $* *$ & NS & $*$ \\
\hline $\mathrm{Y} \times \mathrm{Ir}$ & $*$ & $*$ & $* *$ & $* *$ & * \\
\hline $\mathrm{T} \times \mathrm{Cv}$ & $*$ & * & $*$ & NS & $*$ \\
\hline $\mathrm{T} \times \mathrm{Ir}$ & $* *$ & NS & $* *$ & NS & NS \\
\hline $\mathrm{Cv} \times \mathrm{Ir}$ & $*$ & * & $*$ & $*$ & $*$ \\
\hline $\mathrm{Y} \times \mathrm{T} \times \mathrm{Cv}$ & $* *$ & $* *$ & $* *$ & $*$ & $*$ \\
\hline $\mathrm{Y} \times \mathrm{T} \times \mathrm{Ir}$ & $*$ & NS & $* *$ & NS & NS \\
\hline $\mathrm{T} \times \mathrm{Cv} \times \mathrm{Ir}$ & * & * & * & * & * \\
\hline $\mathrm{Y} \times \mathrm{Cv} \times \mathrm{Ir}$ & $*$ & * & * & $*$ & $*$ \\
\hline $\mathrm{Y} \times \mathrm{T} \times \mathrm{Cv} \times \mathrm{Ir}$ & $*$ & $*$ & * & $*$ & $*$ \\
\hline
\end{tabular}

$*$ : Significance at $\mathrm{P} \leq 0.05 ; * *$ : Significance at $\mathrm{P} \leq 0.01 ; * * *$ : Significance at $\mathrm{P} \leq 0.001$.

Table 3. Effect of infestation by the charcoal rot fungus, Macrophomina phaseolina, on total phenol (g/100g), lignin (mg $\mathrm{GAE} / \mathrm{g})$, total isoflavones ( $\mu \mathrm{g} / \mathrm{mg}), \mathrm{N}, \mathrm{P}, \mathrm{K}, \mathrm{Ca}, \mathrm{Mg}(\%), \mathrm{Mn}, \mathrm{B}, \mathrm{Zn}, \mathrm{Fe}$, and $\mathrm{Cu}(\mathrm{mg} / \mathrm{kg})$ in seeds of irrigated soybean cultivars that are sensitive (DK 3964) or moderately resistant (AG 3905) to charcoal rot infestation in 2004 and 2005.

\begin{tabular}{|c|c|c|c|c|c|c|c|c|c|c|c|c|c|c|}
\hline \multicolumn{15}{|c|}{ 2004, Irrigated } \\
\hline $\begin{array}{l}\text { Source of } \\
\text { variability }\end{array}$ & Infestation & Phenol & Lignin & $\begin{array}{c}\text { Total } \\
\text { isoflavones }\end{array}$ & $\mathrm{N}$ & $\mathrm{P}$ & $\mathrm{K}$ & $\mathrm{Ca}$ & $\mathrm{Mg}$ & $\mathrm{Mn}$ & B & $\mathrm{Zn}$ & $\mathrm{Fe}$ & $\mathrm{Cu}$ \\
\hline DK 3964 & NINF & $4.3 c$ & $7.4 \mathrm{~d}$ & $1732 \mathrm{c}$ & $5.4 \mathrm{a}$ & $0.38 c$ & $1.1 \mathrm{a}$ & $0.21 \mathrm{c}$ & $0.32 b$ & $15.3 \mathrm{c}$ & $33.2 \mathrm{c}$ & $27.5 b$ & $89.5 a$ & $3.6 \mathrm{c}$ \\
\hline AG 3905 & & $5.8 b$ & $8.6 \mathrm{c}$ & $1666 d$ & $4.3 b$ & $0.43 b$ & $1.2 \mathrm{a}$ & $0.36 b$ & $0.38 \mathrm{a}$ & $31.5 b$ & $39.5 b$ & $29.5 b$ & $84.3 a$ & $3.9 \mathrm{c}$ \\
\hline DK 3964 & INF & $5.7 b$ & $9.5 b$ & $1845 b$ & $5.6 a$ & $0.39 c$ & $1.5 \mathrm{a}$ & $0.23 c$ & $0.36 \mathrm{a}$ & $17.5 \mathrm{c}$ & $35.7 \mathrm{c}$ & $28.5 b$ & $104 a$ & $4.3 b$ \\
\hline AG 3905 & & $8.4 \mathrm{a}$ & $13.6 \mathrm{a}$ & $2343 a$ & $4.8 \mathrm{~b}$ & $0.65 a$ & $1.7 \mathrm{a}$ & $0.47 \mathrm{a}$ & $0.35 a$ & 38.3a & $43.6 \mathrm{a}$ & $38.6 \mathrm{a}$ & $98.6 \mathrm{a}$ & $7.8 \mathrm{a}$ \\
\hline \multicolumn{15}{|c|}{ 2005, Irrigated } \\
\hline $\begin{array}{l}\text { Source of } \\
\text { variability }\end{array}$ & Infestation & Phenol & Lignin $^{\mathrm{b}}$ & $\begin{array}{c}\text { Total } \\
\text { isoflavones }\end{array}$ & $\mathrm{N}$ & $\mathrm{P}$ & $\mathrm{K}$ & $\mathrm{Ca}$ & $\mathrm{Mg}$ & Mn & B & $\mathrm{Zn}$ & $\mathrm{Fe}$ & $\mathrm{Cu}$ \\
\hline DK 3964 & NINF & $4.4 \mathrm{c}$ & $6.5 \mathrm{~d}$ & $1453 c$ & $4.6 a$ & $0.31 \mathrm{c}$ & $1.3 \mathrm{c}$ & $0.25 \mathrm{c}$ & $0.23 b$ & $17.5 \mathrm{c}$ & $31.6 b$ & $25.4 \mathrm{~b}$ & 74.7c & $4.6 \mathrm{c}$ \\
\hline AG 3905 & & $5.9 \mathrm{~b}$ & $7.1 \mathrm{c}$ & $1542 b$ & $4.8 \mathrm{a}$ & $0.46 b$ & $1.7 \mathrm{~b}$ & $0.34 \mathrm{~b}$ & $0.31 \mathrm{a}$ & $31.6 b$ & $38.9 b$ & $24.8 b$ & $94.2 \mathrm{a}$ & 5.3a \\
\hline DK 3964 & INF & $5.3 b$ & $8.5 b$ & 1543b & $4.9 \mathrm{a}$ & $0.45 b$ & $1.9 \mathrm{~b}$ & $0.21 \mathrm{c}$ & $0.26 \mathrm{~b}$ & $15.4 \mathrm{C}$ & $38.5 b$ & $24.3 b$ & $80.5 b$ & $5.2 b$ \\
\hline AG 3905 & & $7.6 \mathrm{a}$ & $11.5 \mathrm{a}$ & $1965 a$ & $5.1 \mathrm{a}$ & $0.62 \mathrm{a}$ & $2.4 \mathrm{a}$ & $0.43 a$ & $0.32 \mathrm{a}$ & $38.4 a$ & $53.5 a$ & $41.6 \mathrm{a}$ & $91.6 \mathrm{a}$ & $8.5 a$ \\
\hline
\end{tabular}

The experiment was conducted at Jamie Whitten Delta States Research Center, Stoneville, MS. Means within a column separately followed by the same letter are not significantly different at the 5\% level using Fisher's Least. Lignin was measured in the seed coat. NINF = noninfested; INF = infested. 
both MR and S cultivars increased, but MR cultivars showed higher increase. For example, in S cultivar the increase of phenol, lignin, and isoflavone concentrations was $32.6 \%, 6.5 \%$, and $28.4 \%$, respectively, while the increase of phenol, lignin, and isoflavone concentrations in MR cultivar was $44.8 \%, 40.6 \%$, and $58 \%$, respectively. There were significant differences in phenol, lignin, and isoflavone concentrations between cultivars (Table 3). This pattern was shown in 2004 and 2005. However, in 2005 (Table 3), the concentration of isoflavones was lower than in 2004 due to higher temperature as described before by Mengistu et al. [23]. Seed minerals (K, P, Ca, Mn, B, Zn, and Cu) were higher in MR cultivar than in S cultivar under INF conditions. Seed N and $\mathrm{Mg}$ did not show differences between MR cultivar and S cultivar under INF conditions (Table 3). Mineral concentrations in seed were different between cultivars.

\subsection{Effect of Charcoal Rot Infestation on Seed Phenol, Lignin, Total Isoflavones, and Minerals under Non-Irrigated Conditions}

The concentrations of phenol, lignin, and isoflavones were higher in MR cultivar than in S cultivar (Table 4), although the concentration of isoflavones was significantly lower under non-irrigated conditions in both cultivars under NINF and INF conditions (Table 4). Both cultivars showed higher concentrations of phenol, lignin, and isoflavones under INF than under NINF conditions, although the response of MR cultivar to INF was significantly greater. For example, in S cultivar under INF conditions the concentrations of phenol, lignin, and isoflavones were $25 \%, 15 \%, 6.6 \%$, respectively. However, the concentrations of phenol, lignin, and isoflavones in MR cultivar under INF were 66\%, 72\%, and 21.7\%, respectively. Seed K, P, Ca, Mn, B, Zn, and Cu were higher in MR cultivar than in S cultivar in INF. Seed N, P, B, Zn, and Cu decreased in S cultivar in INF compared with NINF. This observation was observed only under non-irrigated conditions in both years. In MR cultivar, however, the concentrations of $\mathrm{N}$ and $\mathrm{P}$ in seed were maintained, and the concentrations of $\mathrm{B}, \mathrm{Zn}$, and $\mathrm{Cu}$ increased in MR cultivar in INF (Table 4). Generally, the level of minerals was lower in non-irrigated than in irrigated (Table 3 and Table 4).

\subsection{Effect of Charcoal Rot Infestation on Seed Sugars under Irrigated and Non-Irrigated Conditions}

Seed glucose and fructose concentrations were higher in both MR and S cultivars in response to charcoal rot

Table 4. Effect of infestation by the charcoal rot fungus, Macrophomina phaseolina, on total phenol (g/100g), lignin (mg $\mathrm{GAE} / \mathrm{g})$, total isoflavones ( $\mu \mathrm{g} / \mathrm{mg}), \mathrm{N}, \mathrm{P}, \mathrm{K}, \mathrm{Ca}, \mathrm{Mg}(\%), \mathrm{Mn}, \mathrm{B}, \mathrm{Zn}, \mathrm{Fe}$, and $\mathrm{Cu}(\mathrm{mg} / \mathrm{kg})$ in seeds of non-irrigated soybean genotypes that are sensitive (DK 3964, S) or moderately resistant (AG 3905, MR) to charcoal rot infestation in 2004 and 2005.

\begin{tabular}{|c|c|c|c|c|c|c|c|c|c|c|c|c|c|c|}
\hline \multicolumn{15}{|c|}{ 2004, Non-irrigated } \\
\hline $\begin{array}{c}\text { Source of } \\
\text { variability }\end{array}$ & Infestation & Phenol & Lignin & $\begin{array}{c}\text { Total } \\
\text { isoflavones }\end{array}$ & $\mathrm{N}$ & $\mathrm{P}$ & $\mathrm{K}$ & $\mathrm{Ca}$ & $\mathrm{Mg}$ & $\mathrm{Mn}$ & B & $\mathrm{Zn}$ & $\mathrm{Fe}$ & $\mathrm{Cu}$ \\
\hline DK 3964 & NINF & $5.4 \mathrm{~d}$ & $7.3 c$ & $1364 c$ & $4.3 \mathrm{a}$ & $0.21 \mathrm{c}$ & $1.1 \mathrm{c}$ & $0.30 \mathrm{c}$ & $0.28 \mathrm{~b}$ & $13.5 c$ & $32.6 c$ & $19.5 b$ & $68.5 \mathrm{a}$ & $2.5 b$ \\
\hline AG 3905 & & $7.4 \mathrm{~b}$ & $7.9 \mathrm{~b}$ & $1432 b$ & $4.9 a$ & $0.34 b$ & $1.5 b$ & $0.37 b$ & $0.35 a$ & $29.7 b$ & $37.1 b$ & $20.6 b$ & $65.4 \mathrm{a}$ & $2.9 \mathrm{~b}$ \\
\hline DK 3964 & INF & $6.8 \mathrm{c}$ & $8.4 \mathrm{~b}$ & $1454 b$ & $3.1 b$ & $0.12 \mathrm{~d}$ & $0.78 \mathrm{~d}$ & $0.36 b$ & $0.21 b$ & $12.5 \mathrm{c}$ & $21.5 d$ & $13.7 \mathrm{c}$ & $71.5 \mathrm{a}$ & $2.7 \mathrm{~b}$ \\
\hline AG 3905 & & $12.3 a$ & $13.6 a$ & $1743 a$ & $4.7 \mathrm{a}$ & $0.47 \mathrm{a}$ & $2.0 \mathrm{a}$ & $0.53 a$ & $0.37 \mathrm{a}$ & $35.0 \mathrm{a}$ & 46.3a & $32.6 a$ & $69.5 a$ & $5.8 \mathrm{a}$ \\
\hline \multicolumn{15}{|c|}{ 2005, Non-irrigated } \\
\hline $\begin{array}{c}\text { Source of } \\
\text { variability }\end{array}$ & Infestation & Phenol & Lignin $^{b}$ & $\begin{array}{c}\text { Total } \\
\text { isoflavones }\end{array}$ & $\mathrm{N}$ & $\mathrm{P}$ & $\mathrm{K}$ & $\mathrm{Ca}$ & $\mathrm{Mg}$ & Mn & B & $\mathrm{Zn}$ & $\mathrm{Fe}$ & $\mathrm{Cu}$ \\
\hline DK 3964 & NINF & $4.6 \mathrm{c}$ & $5.7 \mathrm{c}$ & $1124 c$ & $4.0 \mathrm{~b}$ & $0.25 b$ & $0.87 \mathrm{~b}$ & $0.24 \mathrm{c}$ & $0.21 \mathrm{c}$ & $13.2 \mathrm{c}$ & $33.2 \mathrm{a}$ & $18.5 b$ & $56.4 \mathrm{~b}$ & $2.0 \mathrm{~b}$ \\
\hline AG 3905 & & $5.4 \mathrm{~b}$ & $6.8 \mathrm{~b}$ & $1254 b$ & $4.8 \mathrm{a}$ & $0.36 \mathrm{a}$ & $1.1 \mathrm{a}$ & $0.32 b$ & $0.34 \mathrm{a}$ & $30.1 b$ & $27.4 \mathrm{~b}$ & $21.4 b$ & $62.4 \mathrm{a}$ & $3.1 \mathrm{a}$ \\
\hline DK 3964 & INF & $5.4 b$ & $4.2 \mathrm{~d}$ & $1025 d$ & $3.1 b$ & $0.13 c$ & $0.73 c$ & $0.21 \mathrm{c}$ & $0.27 \mathrm{~b}$ & $10.1 \mathrm{c}$ & $21.1 \mathrm{c}$ & $11.4 \mathrm{c}$ & $47.5 \mathrm{c}$ & $1.1 \mathrm{C}$ \\
\hline AG 3905 & & $7.8 \mathrm{a}$ & 8.6a & $1543 a$ & $4.7 \mathrm{a}$ & $0.39 a$ & $1.5 \mathrm{a}$ & $0.49 \mathrm{a}$ & $0.36 a$ & $35.6 a$ & $35.4 \mathrm{a}$ & $27.6 \mathrm{a}$ & $59.4 \mathrm{a}$ & $3.5 \mathrm{a}$ \\
\hline
\end{tabular}

The experiment was conducted at Jamie Whitten Delta States Research Center, Stoneville, MS. Means within a column separately followed by the same letter are not significantly different at the 5\% level using Fisher's Least. Lignin was measured in the seed coat. NINF = noninfested; INF = infested. 
infestation (Table 5). Seed sucrose concentration was lower in INF in both MR and S cultivars, although the concentration in MR cultivar was higher than in S cultivar. Seed raffinose and stachyose were higher in INF than in NINF in both cultivars, opposing the trend of sucrose. Glucose, fructose, sucrose, raffinose concentrations were different between cultivars under INF or NINF conditions, but this difference depended on year (Table 5). This general trend was shown in 2004 and 2005 under INF or NINF. However, glucose and fructose concentrations were higher in INF than NINF, especially under non-irrigated conditions in 2004 and 2005 (Table 6), opposing sucrose trend. Raffinose and stachyose concentrations were higher in INF than NINF as opposed to sucrose.

\section{Discussion}

\subsection{Phenolics and Resistance to Charcoal Rot}

The higher concentration of phenolics (phenol, lignin, and isoflavones) in the MR cultivar than in the S cultivar in NINF and INF under irrigated and non-irrigated indicated that phenolics may have a possible role in resistance against charcoal rot. Previous research showed that lignin content can be altered by biotic (fungi, bacteria, and virus) and abiotic stress (heat, drought, and mineral deficiencies) [29]. The increase of phenolics in MR cultivar and its ability to maintain higher levels of phenolics under INF and NINF may reflect a possible mechanism to provide cell wall and seed coat with structural support and integrity against disease infection and drought stress. It was reported that phenolics, including lignin, are major compounds of cell wall and cell integrity, giving rigidity and impermeability properties [33].

The effects of charcoal rot infestation on seed composition and seed phenolics were investigated, and found that there were no significant differences in seed protein levels when MR genotype DT97-4290 was grown under infested or non-infested conditions under irrigated and non-irrigated [22]. On the other hand, Pharoah and Egyptian (S genotypes) did not maintain seed protein and linolenic fatty acid levels under infested conditions compared with non-infested conditions [22] [66]. Also, charcoal rot moderately resistant genotypes DT97-4290 and AG 3905, and their maturity equivalent susceptible genotypes Egyptian and DK 3964 were evaluated, and found that MR genotype had the lowest charcoal rot infection compared with the other genotypes, resulting in better seed quality [22] [65] and production [23] [65]. Our results support the previous research in that lignin could be related with mechanical support, water transport, and defense against pathogens [33] [34], and lignin deposition in the seed coat tissue provides mechanical resistance and cell wall protection against microorganisms.

Table 5. Effect of infestation by the charcoal rot fungus, Macrophomina phaseolina, on sugars (mg/g) in seeds of irrigated soybean genotypes that are sensitive (DK 3964) or moderately resistant (AG 3905) to charcoal rot infestation in 2004 and 2005.

\begin{tabular}{|c|c|c|c|c|c|c|}
\hline \multicolumn{7}{|c|}{ 2004, Irrigated } \\
\hline Source of variability & Infestation & Glucose & Fructose & Sucrose & Raffinose & Stachyose \\
\hline DK 3964 & NINF & $2.5 \mathrm{c}$ & $0.78 \mathrm{c}$ & $43.1 \mathrm{~b}$ & $5.4 \mathrm{c}$ & $46.3 \mathrm{~b}$ \\
\hline AG 3905 & & $3.6 b$ & $0.62 \mathrm{~d}$ & $55.7 \mathrm{a}$ & $4.6 \mathrm{~d}$ & $38.5 c$ \\
\hline DK 3964 & INF & $3.7 b$ & $1.2 \mathrm{~b}$ & $34.6 \mathrm{c}$ & $6.5 b$ & $57.4 \mathrm{a}$ \\
\hline AG 3905 & & $4.6 \mathrm{a}$ & $1.7 \mathrm{a}$ & $46.1 \mathrm{~b}$ & 7.8a & $58.5 \mathrm{a}$ \\
\hline \multicolumn{7}{|c|}{ 2005, Irrigated } \\
\hline Source of variability & Infestation & Glucose & Fructose & Sucrose & Raffinose & Stachyose \\
\hline DK 3964 & NINF & $2.4 \mathrm{~b}$ & $0.87 \mathrm{c}$ & $42.5 b$ & $5.4 \mathrm{c}$ & $46.3 \mathrm{~b}$ \\
\hline AG 3905 & & $1.3 \mathrm{c}$ & $0.79 d$ & 51.3a & $4.6 \mathrm{~d}$ & $38.5 \mathrm{c}$ \\
\hline DK 3964 & INF & $3.5 a$ & $1.3 b$ & $31.2 \mathrm{~d}$ & $6.5 b$ & $42.5 b$ \\
\hline AG 3905 & & $3.2 \mathrm{a}$ & $2.1 \mathrm{a}$ & $39.7 c$ & $7.8 \mathrm{a}$ & $56.3 a$ \\
\hline
\end{tabular}

\footnotetext{
${ }^{\mathrm{a}}$ The experiment was conducted at Jamie Whitten Delta States Research Center, Stoneville, MS. Means within a column separately followed by the
} same letter are not significantly different at the $5 \%$ level using Fisher's Least. NINF = noninfested; INF = infested. 
Table 6. Effect of infestation by the charcoal rot fungus, Macrophomina phaseolina, on sugars (mg/g) in seeds of non-irrigated soybean genotypes that are sensitive (DK 3964) or moderately resistant (AG 3905) to charcoal rot in 2004 and 2005.

\begin{tabular}{|c|c|c|c|c|c|c|}
\hline \multicolumn{7}{|c|}{ 2004, Non-irrigated } \\
\hline Source of variability & Infestation & Glucose & Fructose & Sucrose & Raffinose & Stachyose \\
\hline DK 3964 & NINF & $1.5 \mathrm{~d}$ & $1.1 \mathrm{a}$ & $45.3 b$ & $4.5 \mathrm{~d}$ & $30.6 c$ \\
\hline AG 3905 & & $2.5 c$ & $0.92 \mathrm{~b}$ & 57.3a & $5.2 \mathrm{c}$ & $42.6 b$ \\
\hline DK 3964 & INF & $3.4 \mathrm{~b}$ & $1.7 \mathrm{a}$ & $37.6 \mathrm{c}$ & $6.4 \mathrm{~b}$ & $47.8 \mathrm{~b}$ \\
\hline AG 3905 & & $4.7 \mathrm{a}$ & $1.5 a$ & $48.4 \mathrm{~b}$ & 7.3a & $56.3 a$ \\
\hline \multicolumn{7}{|c|}{ 2005, Non-irrigated } \\
\hline Source of variability & Infestation & Glucose & Fructose & Sucrose & Raffinose & Stachyose \\
\hline DK 3964 & NINF & $3.4 \mathrm{~d}$ & $0.94 b$ & $36.5 c$ & 4.6c & $41.6 b$ \\
\hline AG 3905 & & $4.2 \mathrm{c}$ & $0.82 \mathrm{c}$ & $49.7 \mathrm{a}$ & 3.6d & $38.6 \mathrm{c}$ \\
\hline DK 3964 & INF & $5.7 \mathrm{~b}$ & $1.5 \mathrm{a}$ & $32.5 c$ & $5.8 \mathrm{~b}$ & $47.6 \mathrm{~b}$ \\
\hline AG 3905 & & $6.6 \mathrm{a}$ & $1.9 \mathrm{a}$ & $43.5 b$ & $6.6 a$ & $51.5 a$ \\
\hline
\end{tabular}

The experiment was conducted at Jamie Whitten Delta States Research Center, Stoneville, MS. Means within a column separately followed by the same letter are not significantly different at the $5 \%$ level using Fisher's Least. NINF = noninfested; INF = infested.

When six soybean cultivars were investigated, it was found that the cultivars Doko and Parana had higher content of lignin and peroxidase activities compared with cultivars Savana, Paranagoiana, FT-10, and Santa Rosa, indicating that phenolics, including phenol, lignin, and isoflavones, are associated with defense against charcoal $\operatorname{rot}[35][36]$.

The higher concentrations of total isoflavones in MR cultivar than in S cultivar in NINF and INF under irrigated and non-irrigated indicated also possible association between charcoal rot resistance and isoflavones levels. Our findings are supported by our previous research on charcoal rot and phomopsis seed decay where soybean genotypes resistant to Phomopsis or moderately resistant to charcoal rot showed higher phenol, lignin, and total isoflavones compared with susceptible genotypes [18] [67]. This is also in agreement with previous research, indicating that isoflavones act as a repellant against pathogens [68]. It was reported that the phytoalexins, a class to which isoflavones belong to, are synthesized in plant cells as a response to plant infection by the fungus and a result of the interaction between the host and the pathogen [69]. This interaction between the fungus and the host leads to phytohormones production and de novo expression of the enzymes involved in their biosynthetic pathway [69]. It was shown that after infection, a rapid accumulation of phytoalexins was observed in response to interaction with Phytophthora megasperma [39]. Daidzeinisoflavone, a phytoalexin, was an immediate precursor of the glyceollins and conjugates of daidzein, and was rapidly hydrolyzed to free daidzein during the interactions between soybean and Phytophthora megasperma f. sp. glycinea. Our previous research indicated that individual isoflavones (daidzein, genistein, and glycitein) were higher in genotypes resistant to Phomospsis or moderately resistant to charcoal rot compared with susceptible genotypes [18] [67]. It is still not clear how phytoalexins, including isoflavones are involved in the defense in response to the pathogen attack. Although higher accumulation of isoflavones was observed in MR genotype than in S genotypes in the current research, the mechanisms by which isoflavones are involved in the defense mechanism remain unclear, and further research is needed.

\subsection{Minerals and Resistance to Charcoal Rot}

The higher levels of K, P, Ca, Mn, B, Zn, and Cu in NINF and INF under irrigated and nonirrigated conditions in MR cultivar indicated a possible role of these specific minerals in disease resistance. Although resistance is genetically controlled, mineral nutrition can play a major role in resistance or tolerance to pathogens [37] [38]. It was reported that the effect of mineral nutrition is substantial in moderately susceptible cultivars, but lower in highly susceptible or resistant ones [37]. This may be because some minerals such B, Mn, and Cu play a major 
role in phenolics and lignin synthesis [37] [39] and in cell wall and membrane integrity. It was found that K and Zn deficiencies resulted in high cell wall leakage of sugar and amino acid concentrations to leaf apoplast, allowing the pathogen to penetrate the cell [38] [40]. Also, it was found that B deficiency led to higher fungal infection and low Ca content in plant tissue, resulting in cell wall leakage of sugars and amino acids from cytoplasm to apoplast [41]. Calcium has a role in stability of cell wall through polygalacturonates and in the activity of enzymes like polygalacturonase which dissolves the middle lamella, and both of these two processes were found to be inhibited by Ca deficiency. Copper was found to inhibit diseases, as $\mathrm{Cu}$ deficiency led to impairment of defense compound synthesis, accumulation of soluble carbohydrates, and reduced lignin synthesis, resulting in lower disease resistance [38].

The mechanisms of minerals or phenolics involvement in the disease resistance against the fungus or toxin is not known, but possible explanations can be put forward as follows. Minerals such as $\mathrm{Ca}, \mathrm{B}, \mathrm{Mn}, \mathrm{Cu}$, and phenolics are involved in cell wall integrity and cell membrane permeability and integrity [37]. Biotic or abiotic stress factors that alter the balance of mineral uptake and translocation, phenolics metabolism and lignin synthesis can change the membrane phospholipids and affect cell wall and cell membrane integrity, enhancing the fungal penetration [37]. For example, the higher level of B in MR cultivar than in S cultivar suggests that B may have a role in resistance because of its role in cell membrane and cell wall integrity [18] [67] [70] [71] and its indirect effects on phenol metabolism and lignin biosynthesis [37]. Previous research showed that there is an association between B and phenolics metabolism, affecting disease resistance [18] [37] [67]. Boron has structural and metabolic role [37] and is involved in growth [72], seed quality [73], sugar transport and carbohydrates metabolism, cell wall synthesis, lignification, cell wall structure, RNA metabolism, respiration, indole acetic acid metabolism, phenolics metabolism, membrane integrity [74], ascorbate metabolism [75] and oxygen activation [37]. Previous research indicated that B is involved in formation of boron-pectin complexes [42] [71] [76] and plasma membrane integrity [37] [74]. It is suggested that plant resistance to pathogens occurs when adequate mineral nutrition and regular biosynthesis of phenolics are satisfied. Under these conditions, when a pathogen interacts with the resistant plant, the defense mechanism and signaling system are turned on to respond to the possible pathogen infection. The defense mechanism is achieved at two levels: mechanical at the cell wall level; and biochemical and molecular through a signaling system and gene expression. At the cell wall level, the plant deploys reactive oxygen species (such as superoxide and hydrogen peroxide) and mechanical strength of cell wall (such as lignin) to stop and prevent the pathogen from spreading. If the pathogen succeeds in penetrating the cell, using its toxin or toxin-containing enzymes to degrade the cell wall, then another level of resistance involves a signaling system that is capable of degrading pathogen toxin and toxin-containing enzymes.

\subsection{Sugars and Resistance to Charcoal Rot}

The higher levels of glucose and fructose in both R and S cultivars in INF indicated that these monosaccharides accumulated as a response to disease stress. The decrease of sucrose in INF in both cultivars may be due to the accumulation of glucose and fructose as these monosaccharides are the building block of sucrose. The increase of raffinose and stachyose in INF and under non-irrigated conditions suggested that both raffinose and stachyose may have a role in disease resistance and drought stress tolerance [77]. Although the biological functions of raffinose and stachyose are not well understood [78], oligosaccharides (sucrose, raffinose, and stachyose) contribute to seed quality [79], the acquisition of desiccation tolerance during seed development and maturation and protection of seeds against damage during seed dehydration and aging. Soybean seed raffinose and stachyose are undesirable constituents because they have negative effects on the nutritive value of soymeal and are indigestible by humans and animals, causing flatulence or diarrhea in nonruminants [80]. The soybean seed industry is interested in soybean seed with low raffinose and stachyose levels [81], and a high level of seed glucose, fructose, and sucrose is desirable because it improves the taste and flavor of soy-based products such as tofu, soymilk, and natto [82].

\section{Conclusion}

Our research demonstrated that phenolics, including phenol, lignin, and isoflavones, and specific minerals, including $\mathrm{K}, \mathrm{Ca}, \mathrm{Mn}, \mathrm{B}, \mathrm{Zn}$, and $\mathrm{Cu}$, may significantly contribute to plant defense by preventing pathogen entrance at the cell wall level through cell wall lignin-pectin complex and cell wall mechanical resistance. The increase of glucose and fructose in INF under irrigated and non-irrigated indicated that these sugars accumulated 
due to the lack of conversion to sucrose. The increase of raffinose and stachyose in INF under irrigated and non-irrigated may indicate a significant role of these sugars in disease resistance and drought tolerance during seed maturation. Further research is needed for charcoal rot resistance selection, and to develop a germplasm of near-isogenic lines differing in levels of resistance to charcoal rot, but with similar genetic background to avoid genotype confounding. The negative effects of charcoal rot infection and drought on phenolics, minerals, and sugars in susceptible cultivars present a seed quality challenge.

\section{Acknowledgements}

We thank Sandra Mosley for lab assistance. This research was funded by United States Department of Agriculture, Agricultural Research Service project number 6402-21220-012-00D. The US Department of Agriculture (USDA) is an equal opportunity provider and employer. Mention of trade names or commercial products in this publication is solely for the purpose of providing specific information and does not imply recommendation or endorsement by the US Department of Agriculture.

\section{References}

[1] Messina, M.J., Persky, V., Setchell, K.D. and Barnes, S. (1994) Soy Intake and Cancer Risk: A Review of the in Vitro and in Vivo Data. Nutrition and Cancer, 21, 113-131. http://dx.doi.org/10.1080/01635589409514310

[2] Potter, S.M., Baum, J.A., Teng, H., Stillman, R.J., Shay, N.F., et al. (1998) Soy Protein and Isoflavones: Their Effects on Blood Lipids and Bone Density in Postmenopausal Women. The American Journal of Clinical Nutrition, 68, 1375S1379S.

[3] Sakthivelu, G., Akitha Devi, M.K., Giridhar, P., Rajasekaran, T., Ravishankar, G.A., et al. (2008) Isoflavone Composition, Phenol Content, and Antioxidant Activity of Soybean Seeds from India and Bulgaria. Journal of Agricultural and Food Chemistry, 56, 2090-2095. http://dx.doi.org/10.1021/jf072939a

[4] Wikipedia (2013) http://en.wikipedia.org/wiki/Phenols

[5] Harborne, J.B. (1989) Methods in Plant Biochemistry. In: Dey, P.M. and Harborne, J.B., Eds., Plant Phenolics, Academic Press, London, 283-323.

[6] Lattanzio, V., Veronica, M., Lattanzio, T. and Cardinali, A. (2006) Role of Phenolics in the Resistance Mechanisms of Plants against Fungal Pathogens and Insects In: Imperato, F., Ed., Phytochemistry: Advances in Research, Research Signpost, Kerala, 23-67.

[7] Knaggs, A.R. (2000) The Biosynthesis of Shikimate Metabolites. Natural Product Reports, 18, 334-355. http://dx.doi.org/10.1039/b001717p

[8] Aoki, T., Akashi, T. and Ayabe, S. (2000) Flavonoids of Leguminous Plants: Structure, Biological Activity, and Biosynthesis. Journal of Plant Research, 113, 475-488. http://dx.doi.org/10.1007/PL00013958

[9] Whiting, D.A. (2001) Natural Phenolic Compounds 1900-2000: A Bird’s Eye View of a Century’s Chemistry. Natural Product Reports, 18, 583-606.

[10] Wyllie, T.D. (1976) Macrophomina Phaseolina, Charcoal Rot. In: Hill, L.D., Ed., World Soybean Research: Proceedings of the World Soybean Research Conference, Interstate Printers and Publishers Inc., Danville, 482-484.

[11] Mengistu, A., Ray, J.D., Smith, J.R. and Paris, R.L. (2007) Charcoal Rot Disease Assessment of Soybean Genotypes Using a Colony-Forming Unit Index. Crop Science, 47, 2453-2461. http://dx.doi.org/10.2135/cropsci2007.04.0186

[12] Hill, J.H., Bailey, T.B., Benner, H.I., Tachibana, H. and Durand, D.P. (1987) Soybean Mosaic Virus: Effects of Primary Disease Incidence on Yield and Seed Quality. Plant Disease, 71, 237-239. http://dx.doi.org/10.1094/PD-71-0237

[13] Mengistu, A. and Heatherly, L.G. (2006) Planting Date, Irrigation, Maturity Group, Year, and Environment Effects on Phomopsis longicolla, Seed Germination, and Seed Health Rating of Soybean in the Early Soybean Production System of the Midsouthern USA. Crop Protection, 25, 310-317. http://dx.doi.org/10.1016/j.cropro.2005.05.011

[14] Kulik, M.M. and Sinclair, J.B. (1999) Phomposis Seed Decay. In: Hartman, G.L., Sinclair, J.B. and Rupe, J.C., Eds., Compendium of Soybean Diseases, APS Press, The American Phytopathological Society, St. Paul, 31-32.

[15] Siddiqui, K.A., Gupta, A.K., Paul, A.K. and Banerjee, A.K. (1979) Purification and Properties of Heat-Resistant Exotoxin Produced by Macrophomina phaseolina (Tassi) Goid in Culture. Experientia, 35, 1222-1223. http://dx.doi.org/10.1007/BF01963302

[16] Dhar, T.K., Siddiqui, K.A.I. and Ali, E. (1982) Structure of Phaseolinone, a Novel Phytotoxin from Macrophomina phaseolina. Tetrahedron Letters, 23, 5459-5462.

[17] Ramezani, M., Shier, W.T., Abbas, H.K., Tonos, J.L., Baird, R.E., et al. (2007) Soybean Charcoal Rot Disease Fungus 
Macrophomina phaseolina in Mississippi Produces the Phytotoxin (-)-Botryodiplodin but No Detectable Phaseolinone. Journal of Natural Products, 70, 28-129. http://dx.doi.org/10.1021/np060480t

[18] Bellaloui, N., Mengistu, A., Fisher, D.K. and Abel, C.A. (2012) Soybean Seed Composition as Affected by Drought and Phomopsis in Phomopsis Susceptible and Resistant Genotypes. Journal of Crop Improvement, 26, 428-453. http://dx.doi.org/10.1080/15427528.2011.651774

[19] Smith, G.S. and Wyllie, T.D. (1999) Charcoal Rot. In: Hartman, G.L., Sinclair, J.B. and Rupe, J.C., Eds., Compendium of Soybean Disease, APS Press, American Phytopathological Society, St. Paul, 29-31.

[20] Kendig, S.R., Rupe, J.C. and Scott, H.D. (2000) Effect of Irrigation and Soil Water Stress on Densities of Macrophomina phaseaolina in Soil and Roots of Two Soybean Cultivars. Plant Disease, 84, 895-900. http://dx.doi.org/10.1094/PDIS.2000.84.8.895

[21] Paris, R.L., Mengistu, A., Tyler, J.M. and Smith, J.R. (2006) Registration of Soybean Germplasm Line DT97-4290 with Moderate Resistance to Charcoal Rot. Crop Science, 46, 2324-2325. http://dx.doi.org/10.2135/cropsci2005.09.0297

[22] Bellaloui, N., Mengistu, A. and Paris, R.L. (2008) Soybean Seed Composition in Cultivars Differing in Resistance to Charcoal Rot (Macrophomina phaseolina). Journal of Agricultural Sciences, 146, 667-675. http://dx.doi.org/10.1017/S0021859608007971

[23] Mengistu, A., Smith, J.R., Ray, J.D. and Bellaloui, N. (2011) Seasonal Progress of Charcoal Rot and Its Impact on Soybean Productivity. Plant Disease, 95, 1159-1166. http://dx.doi.org/10.1094/PDIS-02-11-0100

[24] Kim, S.H., Jung, W.S., Ahn, J.K. and Chung, I.M. (2005) Analysis of Isoflavone Concentration and Composition in Soybean [Glycine max (L.)] Seeds between the Cropping Year and Storage for 3 Years. European Food Research and Technology, 220, 207-214. http://dx.doi.org/10.1007/s00217-004-1048-5

[25] Riedl, K.M., Lee, J.H., Renita, M., St Martin, S.K., Schwartz, S.J., et al. (2007) Isoflavone Profiles, Phenol Content, and Antioxidant Activity of Soybean Seeds as Influenced by Cultivar and Growing Location in Ohio. Journal of the Science of Food and Agriculture, 87, 1197-1206. http://dx.doi.org/10.1002/jsfa.2795

[26] Anderson, J.W., Johnstone, B.M. and Cook-Newell, M.E. (1995) Meta-Analysis of the Effects of Soy Protein Intake on Serum Lipids. The New England Journal of Medicine, 333, 276-282. http://dx.doi.org/10.1056/NEJM199508033330502

[27] Pratt, D.E. and Birac, P.M. (1979) Sources of Antioxidant Activity of Soybeans and Soy Products. Journal of Food Science, 44, 1720-1727. http://dx.doi.org/10.1111/j.1365-2621.1979.tb09125.x

[28] Hu, H., Brown, P.H. and Labavitch, J.H. (1996) Species Variability in Boron Requirement Is Correlated with Cell Wall Pectin. Journal of ExperimentalBotany, 47, 227-232. http://dx.doi.org/10.1093/jxb/47.2.227

[29] Moura, J.C., Bonine, C.A., Viana, J.D.O.F., Dornelas, M.C. and Mazzafera, P. (2010) Abiotic and Biotic Stresses and Changes in the Lignin Content and Composition in Plants. Journal of Integrated Plant Biology, 52, 360-376. http://dx.doi.org/10.1111/j.1744-7909.2010.00892.x

[30] Freudenberg, K. and Neish, A.C. (1968) Constitution and Biosynthesis of Lignin. Springer-Verlag, Berlin, 129. http://dx.doi.org/10.1007/978-3-642-85981-6

[31] Chabannes, M., Ruel, K., Yoshinaga, A., Chabbert, B., Jauneau, A., et al. (2001) In Situ Analysis of Lignins in Transgenic Tobacco Reveals a Differential Impact of Individual Transformations on the Spatial Patterns of Lignin Deposition at the Cellular and Subcellular Levels. Plant Journal, 28, 271-282. http://dx.doi.org/10.1046/j.1365-313X.2001.01159.x

[32] Wikipedia. Natural Phenol. Accessed on August 9, 2013. http://en.wikipedia.org/wiki/Natural_phenol

[33] Campbell, M.M. and Sederoff, R.R. (1996) Variation in Lignin Content and Composition (Mechanisms of Control and Implications for the Genetic Improvement of Plants. Plant Physiology, 110, 3-13.

[34] Lewis, N.G. and Yamamoto, E. (1990) Lignin: Occurrence, Biogenesis and Biodegradation. Annual Review of Plant Physiology and Plant Molecular Biology, 41, 455-496. http://dx.doi.org/10.1146/annurev.pp.41.060190.002323

[35] Krzyzanowski, F.C., Franca-Neto, J.B., Mandarino, J.M.G. and Kaster, M. (2008) Evaluation of Lignin Content of Soybean Seed Coat Stored in a Controlled Environment. Revista Brasileira de Sementes, 30, 220-223. http://dx.doi.org/10.1590/S0101-31222008000200028

[36] Capeleti, I., Bonini, E.A., Lourdes, M.D., Ferrarese, L., Teixeira, A.C.N., et al. (2005) Lignin Content and Peroxidase Activity in Soybean Seed Coat Susceptible and Resistant to Mechanical Damage. Acta Physiologiae Plantarum, 27, 103-108.

[37] Marschner, H. (1995) Mineral Nutrition of Higher Plants. Academic Press, San Diego, 379-396.

[38] Spann, T.M. and Schumann, A.W. (2010) Mineral Nutrition Contributes to Plant Disease and Pest Resistance. One of a Series of the Horticultural Sciences Department, Florida Cooperative Extension Service, Institute of Food and Agricul- 
tural Sciences, University of Florida, IFAS Extension, This document is HS1181. http://edis.ifas.ufl.edu

[39] Graham, N. and Graham, M.Y. (1991) Gyceollinelicitors Induce Major but Distinctly Different Shifts in Isoflavonoid Metabolism in Proximal and Distal Soybean Cell Populations. Molecular Plant-Microbe Interactions, 4, 60-68. http://dx.doi.org/10.1094/MPMI-4-060

[40] Bolle-Jones, E.W. and Hilton, R.N. (1956) Zinc-Deficiency of Hevea brasiliensis as a Predisposing Factor to Oidium Infection. Nature, 177, 619-620. http://dx.doi.org/10.1038/177619b0

[41] Schutte, K.H. (1967) The Influence of Boron and Copper Deficiency upon Infection by Erysiphe graminis D.C., the Powdery Mildew, in Wheat var. Kenya. Plant and Soil, 27, 450-452. http://dx.doi.org/10.1007/BF01376338

[42] Heatherly, L.G., Elmore, C.D., Wesley, R.A. and Spurlock, S.R. (2001) Row Spacing and Weed Management Systems for Non-Irrigated Early Soybean Production System Plantings in the Midsouthern USA. Crop Science, 41, 784-791. http://dx.doi.org/10.2135/cropsci2001.413784x

[43] Ray, J.D., Heatherly, L.G. and Fritschi, F.B. (2006) Influence of Large Amounts of Nitrogen on Non-Irrigated and Irrigated Soybean. Crop Science, 46, 52-60. http://dx.doi.org/10.2135/cropsci2005.0043

[44] Alvarez, P.J.C., Krzyzanowski, F.C., Mandarino, J.M.G. and Franca-Neto, J.B. (1997) Relationship between Soybean Seed Coat Lignin Content and Resistance to Mechanical Damage. Seed Science and Technology, 25, 209-214.

[45] Krzyzanowski, F.C., Franca-Neto, J.B., Mandarino, J.M.G. and Kaster, M. (2001) Comparison Between Two Gravimetric Methods to Determine the Lignin Content in Soybean Seed Coat. Seed Science and Technology, 29, 619-624.

[46] Zobiole, L.H.S., Bonini, E.A., Oliveira Jr., R.S., Kremer, R.J. and Ferrarese-Filho, O. (2010) Glyphosate Affects Lignin Content and Amino Acid Production in Glyphosate-Resistant Soybean. Acta Physiologiae Plantarum, 32, 831-837.

[47] Ferrarese, M.L.L., Zottis, A. and Ferrarese-Filho, O. (2002) Protein-Free Lignin Quantification in Soybean (Glycine max) Roots. Biologia, 57, 541-543.

[48] Qin, G.Z. and Tian, S.P. (2005) Enhancement of Biocontrol Activity of Cryptococcus laurentii by Silicon and the Possible Mechanisms Involved. Phytopathology, 95, 69-75. http://dx.doi.org/10.1094/PHYTO-95-0069

[49] Singleton, V.L. and Rossi, J.A. (1965) Colorimetry of Total Phenolics with Phosphomolybdic-Phosphotungstic Acid Reagents. American Journal of Enology and Viticulture, 16, 144-158.

[50] Xu, B.J. and Chang, S.K. (2007) A Comparative Study on Phenolic Profiles and Antioxidant Activities of Legumes as Affected by Extraction Solvents. Journal of Food Science, 72, S159-S166. http://dx.doi.org/10.1111/j.1750-3841.2006.00260.x

[51] Morrison, M.J., Cober, E.R., Saleem, M.F., McLaughlin, N.B., Fregeau-Reid, J., et al. (2008) Changes in Isoflavone Concentration with 58 Years of Genetic Improvement of Short-Season Soybean Cultivars in Canada. Crop Science, 48, 2201-2208. http://dx.doi.org/10.2135/cropsci2008.01.0023

[52] Sato, T., Eguchi, K., Hatano, T. and Nishiba, Y. (2008) Use of Near-Infra Red Reflectance Spectroscopy for the Estimation of Isoflavone Contents of Soybean Seeds. Plant Production Science, 11, 481-486. http://dx.doi.org/10.1626/pps.11.481

[53] Wilcox, J.R. and Shibles, R.M. (2001) Interrelationships Among Seed Quality Attributes in Soybean. Crop Science, 41, 11-14. http://dx.doi.org/10.2135/cropsci2001.41111x

[54] Bellaloui, N., Smith, J.R., Gillen, A.M. and Ray, J.D. (2010) Effect of Maturity on Seed Sugars as Measured on NearIsogenic Soybean (Glycine max) Lines. Crop Science, 50, 1978-1987. http://dx.doi.org/10.2135/cropsci2009.10.0596

[55] (2012) Sigma USA, Glucose (HK) Assay Kit Product Code GAHK-20. Product Ininformation. http://www.sigmaaldrich.com/etc/medialib/docs/Sigma/Bulletin/gahk20bul.Par.0001.File.tmp/gahk20bul.pdf

[56] Bellaloui, N., Hu, Y., Mengistu, A., Kassem, M.A. and Abel, C.A. (2013) Effects of Foliar Boron Application on Seed Composition, Cell Wall Boron, and Seed ${ }^{15} \delta \mathrm{N}$ and ${ }^{13} \delta \mathrm{C}$ Isotopes in Water-Stressed Soybean Plants. Frontiers in Plant Science, 4, 1-12. http://dx.doi.org/10.3389/fpls.2013.00270

[57] (2012) Sigma USA, Fructose Assay Kit, Product Code FA-20. Product Ininformation. http://www.sigmaaldrich.com/etc/medialib/docs/Sigma/Bulletin/fa20bul.Par.0001.File.tmp/fa20bul.pdf

[58] Dordas, C. (2006) Foliar Boron Application Improves Seed Set, Seed Yield, and Seed Quality of Alfalfa. Agronomy Journal, 98, 907-913. http://dx.doi.org/10.2134/agronj2005.0353

[59] Dordas, C., Apostolides, G. and Goundra, O. (2007) Boron Application Affects Seed Yield and Seed Quality of Sugar Beets. Journal of Agricultural Sciences, 145, 377-384. http://dx.doi.org/10.1017/S0021859607006879

[60] John, M.K., Chuah, H.H. and Neufeld, J.H. (1975) Application of Improved Azomethine-H Method to the Determination of Boron in Soils and Plants. Analytical Letters, 8, 559-568. http://dx.doi.org/10.1080/00032717508058240

[61] Bandemer, S.L. and Schaible, P.J. (1944) Determination of Iron. A Study of the O-Phenanthroline Method. Industrial 
and Engineering Chemistry, Analytical Edition, 16, 317-319. http://dx.doi.org/10.1021/i560129a013

[62] (1959) Analytical Methods Committee, Analysts. Her Majesty’s Stationery Office, London, 84.

[63] Bellaloui, N., Smith, J.R., Gillen, A.M. and Ray, J.D. (2011) Effects of Maturity, Genotypic Background, and Temperature on Seed Mineral Composition in Near-Isogenic Soybean Lines in the Early Soybean Production System. Crop Science, 51, 1161-1171. http://dx.doi.org/10.2135/cropsci2010.04.0187

[64] Cavell, A.J. (1955) The Colorimetric Determination of Phosphorus in Plant Materials. Journal of the Sciences of Food and Agriculture, 6, 479-480. http://dx.doi.org/10.1002/jsfa.2740060814

[65] SAS (2001) SAS 9.1 TS LeVel 1M3, Windows Version 5.1.2600. SAS Institute, Cary.

[66] Mengistu, A., Smith, J.R., Bellaloui, N., Paris, R.L. and Wrather, J.A. (2010) Irrigation and Time of Harvest: Effects on Evaluation of Selected Soybean Accessions against Phomopsis longicolla. Crop Science, 50, 2055-2064. http://dx.doi.org/10.2135/cropsci2009.11.0657

[67] Bellaloui, N., Mengistu, A., Zobiole, L.H.S. and Shier, W.T. (2012) Resistance to Toxin-Mediated Fungal Infection: Role of Lignins, Isoflavones, Other Seed Phenolics, Sugars, and Boron in the Mechanism of Resistance to Charcoal Rot Disease in Soybean. Toxin Reviews, 31, 16-26. http://dx.doi.org/10.3109/15569543.2012.691150

[68] Dixon, R.A. and Steele, C.L. (1999) Flavonoids and Isoflavonoids-A Gold Mine for Metabolic Engineering. Trends in Plant Science, 4, 394-400. http://dx.doi.org/10.1016/S1360-1385(99)01471-5

[69] Paxton, J.D. (1980) A New Working Definition of the Term "Phytoalexin”. Plant Disease, 64, 734.

[70] Hu, H. and Brown, P.H. (1994) Localization of Boron in Cell Walls of Squash and Tobacco and its Association with Pectin (Evidence for a Structural Role of Boron in the Cell Wall). Plant Physiolgy, 105, 681-689.

[71] Bellaloui, N. and Brown, P.H. (1998) Cultivar Differences in Boron Uptake and Distribution in Celery (Apium graveolens), Tomato (Lycopersicon esculentum) and Wheat (Triticum aestivum). Plant and Soil, 198, 153-158. http://dx.doi.org/10.1023/A:1004343031242

[72] Cakmak, I. and Romheld, V. (1997) Boron Deficiency-Induced Impairments of Cellular Functions in Plants. Plant and Soil, 193, 71-83. http://dx.doi.org/10.1023/A:1004259808322

[73] Bellaloui, N., Reddy, K.N., Gillen, A.M. and Abel, C.A. (2010) Nitrogen Metabolism and Seed Composition as Influenced by Foliar Boron Application in Soybean. Plant and Soil, 336, 143-155. http://dx.doi.org/10.1007/s11104-010-0455-6

[74] Parr, A.J. and Loughman, B.C. (1983) Boron and Membrane Function in Plants. In: Robb, D.A. and Pierpoint, W.S., Eds., Metals and Micronutrients, Uptake and Utilization by Plants, Academic Press, New York, 87-107.

[75] Lukaszewski, K.M. and Blevins, D.G. (1996) Root Growth Inhibition in Boron-Deficient or Aluminum-Stressed Squash May Be a Result of Impaired Ascorbate Metabolism. Plant Physiolgy, 112, 1135-1140.

[76] Hu, H., Brown, P.H. and Labavitch, J.M. (1996) Species Variability in Boron Requirement Is Correlated with Cell Wall Pectin. Journal of Experimental Botany, 47, 227-232. http://dx.doi.org/10.1093/jxb/47.2.227

[77] Matoh, T. (1997) Boron in Plant Cell Walls. Plant and Soil, 193, 59-70. http://dx.doi.org/10.1023/A:1004207824251

[78] Brown, P.H., Bellaloui, N., Wimmer, M.A., Bassil, E.S., Ruiz, J., et al. (2002) Boron in Plant Biology. Plant Biology, 4, 205-223. http://dx.doi.org/10.1055/s-2002-25740

[79] Cakmak, I., Kurz, H. and Marschner, H. (1995) Short-Term Effects of Boron, Germanium, and High Light Intensity on Membrane Permeability in Boron Deficient Leaves of Sunflower. Physiologia Plantarum, 95, 11-18.

[80] Taji, T., Ohsumi, C., Iuchi, S., Seki, M., Kasuga, M., et al. (2002) Important Roles of Drought- and Cold-Inducible Genes for Galactinol Synthase in Stress Tolerance in Arabidopsis thaliana. Plant Journal, 29, 417-426. http://dx.doi.org/10.1046/j.0960-7412.2001.01227.x

[81] Ren, C., Bilyeu, K.D. and Beuselinck, P.R. (2009) Composition, Vigor, and Proteome of Mature Soybean Seeds Developed under High Temperature. Crop Science, 49, 1010-1022. http://dx.doi.org/10.2135/cropsci2008.05.0247

[82] Liu, K. (1997) Soybeans Chemistry, Technology, and Utilization. Chapman \& Hall, New York. 
Scientific Research Publishing (SCIRP) is one of the largest Open Access journal publishers. It is currently publishing more than 200 open access, online, peer-reviewed journals covering a wide range of academic disciplines. SCIRP serves the worldwide academic communities and contributes to the progress and application of science with its publication.

Other selected journals from SCIRP are listed as below. Submit your manuscript to us via either submit@scirp.org or Online Submission Portal.
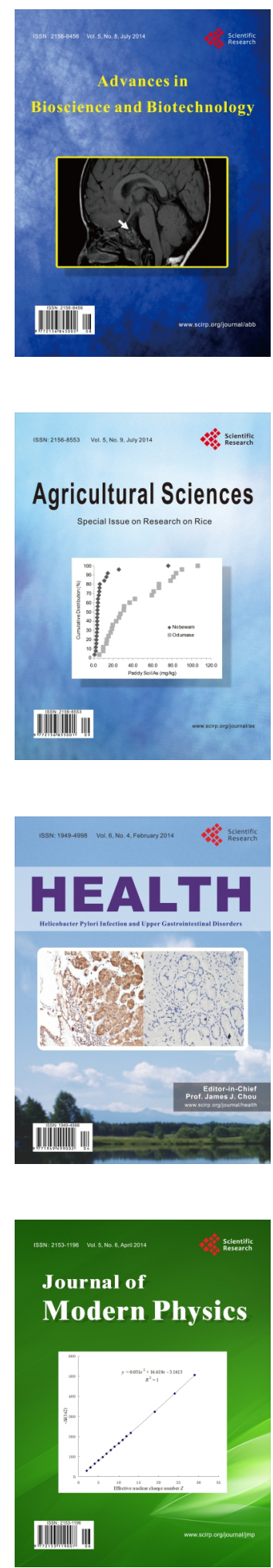
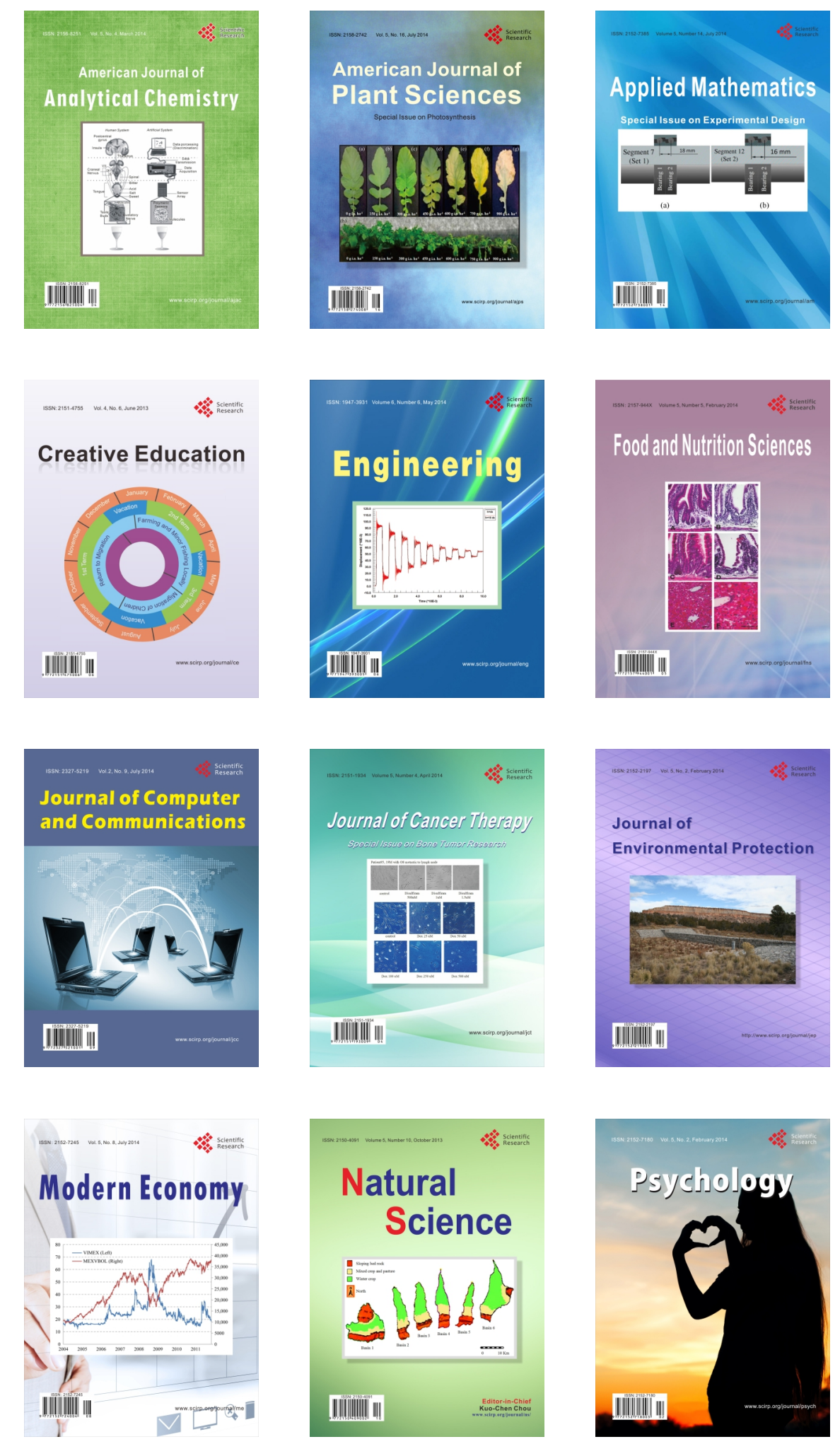